\title{
The Early Commitment of Fetal Neurons to the Limbic Cortex
}

\author{
Mary F. Barbe and Pat Levitt \\ Department of Anatomy and Neurobiology, The Medical College of Pennsylvania, Philadelphia, Pennsylvania 19129
}

The limbic-system-associated membrane protein (LAMP) is expressed early in cerebral cortical development by migrating and postmigratory neurons in limbic regions such as the prefrontal and perirhinal cortices (Horton and Levitt, 1988), but not by nonlimbic neurons such as in the primary sensory and motor cortices. In the present study, we used LAMP expression to evaluate the timing and potential cell-lineage and environmental determinants of the commitment of cerebral cortical neurons to limbic and nonlimbic phenotypes. The cerebral wall, containing either presumptive perirhinal or sensorimotor cortex, was removed prior to [embryonic day (E) 12, 14] or just after (E17) the onset of LAMP expression, labeled with fast blue, and placed into cavities in either perirhinal or sensorimotor regions of postnatal day (P) 1 hosts. Host animals were allowed to survive until at least P10, and surviving transplanted cells were counted and evaluated for LAMP expression. Sensorimotor cortical neurons transplanted at E14 or E17, in either homotopic or heterotopic locations, did not express LAMP. In contrast, a high percentage of perirhinal cortical neurons transplanted at either E14 or E17, whether situated in sensorimotor or perirhinal regions of the host, expressed the limbic marker protein. Surprisingly, neurons from E12 donors exhibited patterns of LAMP expression that reflected their new location in the host rather than their embryonic origin. The data suggest that there is an early pliant period in which precursor and early differentiating cells remain uncommitted to a particular cortical regional phenotype. After this period, one aspect of the molecular phenotype (determined by LAMP expression) of neurons destined for sensorimotor and allo- and mesocortical regions has become immutable by environmental factors in the host.

Specification of brain regions may be regulated by both genetic and epigenetic factors (Rakic, 1974, 1988; Cowan et al., 1984; O'Leary, 1989). While a number of modifications in brain cytoarchitecture have been attributed directly to specific genetic mutations (Rakic, 1974; Caviness and Rakic, 1978; Nowakowski, 1987), the specific forces on a particular CNS cell type that may regulate its development and ultimate phenotypic fate

\footnotetext{
Received June 6, 1990; revised Sept. 7, 1990; accepted Sept. 26, 1990.

We are grateful to our colleagues, Drs. Timothy Cunningham, Kathie Eagleson, Michael Goldberger, Forrest Haun, and Marion Murray for their criticisms. Discussions with Dr. Dennis O'Leary were important contributions to the concepts of neo- and limbic cortex fates discussed in this paper. This work was supported by NIH Grant MH 45507, March of Dimes Research Grant 1-919, NINDS Training Grant NS07287, and NRSA Award 1 F32 NS08561 to M.F.B.

Correspondence should be addressed to Dr. Pat Levitt, Department of Anatomy and Neurobiology, Medical College of Pennsylvania, 3200 Henry Avenue, Philadelphia, PA 19129.

Copyright (C) 1991 Society for Neuroscience $0270-6474 / 91 / 110519-15 \$ 03.00 / 0$
}

have been more difficult to identify. In the study of cerebral cortex specification, several hypotheses have been generated that implicate both lineage-based and environmental mechanisms (Jensen and Killackey, 1984; McConnell, 1988; Rakic, 1988; O'Leary, 1989, O'Leary and Stanfield, 1989). In a classic example of both factors influencing cortical development, thalamic afferents to the somatosensory cortex were removed at birth in the rat. This removal of afferents does not affect the overall development of dense aggregates of granule neurons in layer IV of the somatosensory cortex, but subsidiary features such as the barrels within the aggregates fail to develop (Wise and Jones, 1978).

Transplantation studies using presumptive cortical tissue have attempted to address issues concerning the areal specificity of cerebral cortex (Floeter and Jones, 1984; McConnell, 1988; Hohmann, 1989; O'Leary and Stanfield, 1989). For example, the projection patterns developed by transplanted corticofugal neurons are determined by the new areal location of the transplanted cells in the host (O'Leary and Stanfield, 1989). These results suggest that interactions within a specific locale may be critical in defining at least one aspect of neocortical neuron phenotype, their projection patterns. In contrast, abnormal radial position of neurons in the cerebral hemisphere, induced by ionizing radiation, does not appear to alter the commitment of cortical cells to develop normal projection patterns (Jensen and Killackey, 1984). In another study, it was found recently that some cells exhibit restricted fates, such that cells migrate to their appropriate laminae in the neocortex whose development is temporally inappropriate for the transplanted cells (McConnell, 1988). The faithful expression of their laminar phenotype appears to be independent of the changes in local cues that may occur during different periods of development.

In each of these studies, the identification of appropriate or inappropriate phenotype was based on the expression of a specific anatomical feature (e.g., projection pattern or laminar location). Cellular phenotype can also be evaluated on the basis of expression of unique molecules, a feature that has facilitated the identification of specific populations of neurons that express distinct neurotransmitters (Bloom, 1984; Berger et al., 1985; Levitt, 1985; Denis-Donini, 1989; Morris and Gibbins, 1989), second messengers (DeCamilli et al., 1984; Huang et al., 1988; Mochly-Rosen et al., 1987), and cell-surface molecules (Hockfield and McKay, 1983; McKay et al., 1983; Dodd et al., 1984; Levitt, 1984, 1985; Valentino and Reichardt, 1985, for review; Moskal et al., 1986; Barnstable, 1987; von der Weid and Zurn, 1990). Cytoarchitectonic specification, at the molecular level, has been more difficult to demonstrate. Olfactory regions have been shown to express unique molecules (Margolis, 1972; Farbman and Margolis, 1980; Schwob and Gottlieb, 1988; Croucher and Tickle, 1989; Verhaagen et al., 1989). Recently, a 64-68- 

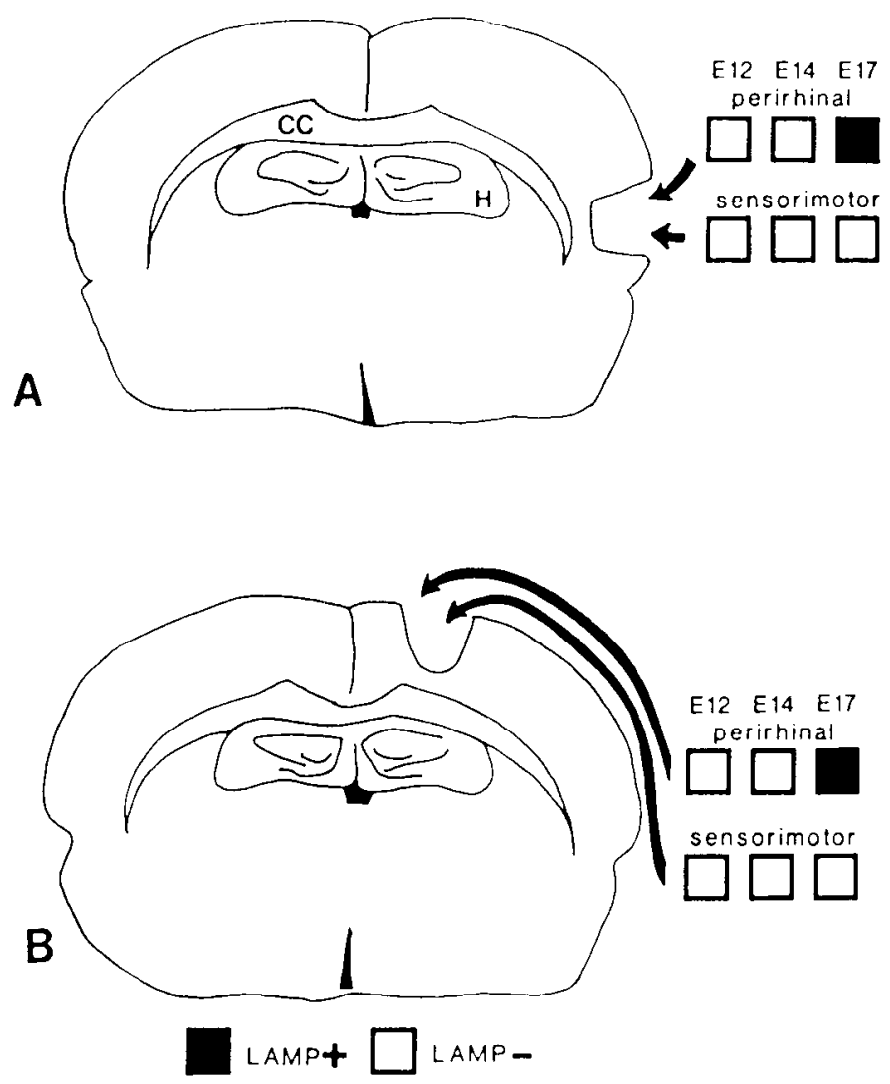

Figure 1. Diagram illustrating transplant paradigms used in present study. The cerebral wall, including the presumptive perirhinal and sensorimotor cortices, was excised as slabs from E12, E14, and E17 rat fetuses and transplanted into a cavity in the perirhinal $(A)$ or sensorimotor cortex $(B)$ of P1 hosts. Transplanted areas can be recognized up to $18 \mathrm{~d}$ after transplantation by virtue of their labeling with fast blue. Open boxes indicate cortical areas from the donor that do not show LAMP immunoreactivity at the time of transplantation; solid boxes indicate areas that are immunoreactive for LAMP at the time of transplantation. Abbreviations: $C C$, corpus callosum; $H$, hippocampus.

$\mathrm{kDa}$ mcmbranc glycoprotein was localized in cortical and subcortical areas of the mammalian brain's limbic system (Levitt, 1984; Levitt et al., 1986; Zacco et al., 1990). The limbic-systemassociated membrane protein (LAMP) is expressed early in fetal development on fiber tracts and in target areas of limbic fiber systems (Horton and Levitt, 1988). In the cerebral cortex, LAMP is expressed initially on postmitotic neurons that are in transit to the cortical plate in meso- and allocortical regions, such as the prefrontal, cingulate, perirhinal, and hippocampal areas. In nonlimbic areas, for example, the primary sensory and motor cortices, neurons never express LAMP. This specificity is maintained during histogenesis and into adulthood. Thus, LAMP serves as an early and permanent marker of neuronal populations that will constitute specific, architectonically well-defined areas of the cerebral cortex.

The present study utilized this phenotypic feature of the limbic cortex to examine the commitment of cortical neurons to limbic fates. Transplantation of fetal cell populations prior to or just after the onset of LAMP expression was performed by using presumptive limbic (perirhinal) and nonlimbic (sensorimotor) areas of the cerebral wall and placing them into homotopic and heterotopic locations of newborn hosts. The monitoring of LAMP expression by immunocytochemical methods was used as an assay of intrinsic and local host influences on the molecular fate of these 2 phenotypically distinct populations of neurons.

\section{Materials and Methods}

Timed pregnant Sprague-Dawley rats were housed in separate cages in a 12-hr light: dark cycle with free access to food and water. A total of 70 host rats at postnatal day $1(\mathrm{P} 1)$ were used. Twenty-six successful heterotopic transplants from donor animals aged embryonic day (E) 12 (8 recipients), E14 (8 recipients), and E17 (10 recipients) were analyzed. Plug date is defined as E0; the date of birth is considered to be P0. Appropriate homotopic controls of presumptive perirhinal tissue transplanted into the perirhinal cortex and presumptive sensorimotor tissue transplanted into the sensorimotor cortex were performed to ensure neuron survival after excision, dye labeling, and transplantation. Twenty-five successful homotopic transplants from donor animals aged E12 (8 recipients), E14 (8 recipients), and E17 (9 recipients) were analyzed.

Cortical transplantation. Variations of a basic heterotopic transplant strategy were used. The transplant paradigm is summarized in Figure 1. Areas of the cerebral wall containing presumptive perirhinal and sensorimotor cortical areas were excised as blocks from rat fetuses at $E 12, E 14$, and $E 17$ and were transplanted into perirhinal or sensorimotor areas of Pl hosts. By selecting these developmental time points, we transplanted presumptive limbic cortical cells either before LAMP is expressed (E12 and E14) or after LAMP is expressed (E17; see Fig. 2). At E12, the cerebral wall is comprised of a cell-proliferative area (ventricular zone) and a cell-free marginal zone. At E14, the wall consists of a ventricular zone, an intermediate zone containing postmitotic migrating neurons, an early cortical plate that consists of postmigratory cells, and a marginal zone. At E17, the same fetal zones as noted for the E14 cerebral wall are present, with a larger cortical plate and a smaller mitotic region in the ventricular zone. The fetal zones correspond to the nomenclature as defined by the Boulder Committee (1970).

Pregnant rats were anesthetized with Nembutal $(50 \mathrm{mg} / \mathrm{kg}$ body weight $)$, the uterine horns were excised, and the fetuses were removed. The fctuses were anesthetized by hypothermia, and the desired areas of brains were rapidly dissected in ice-cold $\mathrm{F} 10$ medium supplemented with $6.5 \mathrm{mg} / \mathrm{ml}$ glucose (Gibco). The meninges were carefully removed, and, with the aid of a surgical microscope, the appropriate area of the wall was dissected as a $0.4-\mathrm{mm}^{3}$ slab. The slabs were labeled with $0.002 \%$ fast blue in cold F10 (stock $=0.02 \%$ fast blue in water, diluted in F10) for $20 \mathrm{~min}$ with gentle agitation. The tissue was washed in 3-5 changes of F10 for $5 \mathrm{~min}$ each to remove residual unincorporated dye. The host rat pups (P1) were anesthetized by hypothermia, and the skull over the desired areas was cut and pulled aside as a flap. Transplants into sensorimotor cortex were made $1 \mathrm{~mm}$ rostral to the bregma and $1.5 \mathrm{~mm}$ lateral to the sagittal suture. Transplants into the perirhinal sulcal cortex were made $1 \mathrm{~mm}$ rostral to the bregma and $1 \mathrm{~mm}$ inferior to the temporoparietal-occipital suture. In each host site, a small amount of cortcx was removed by suction. The tissue plug was carefully set in place. Avitene (UpJohn Co.) was placed on top of the transplant before the skull flap was closed.

Experimental analysis. Ten to 14 d posttransplantation (P11-15), all host animals for each group were deeply anesthetized (Nembutal), perfused transcardially with normal saline followed by $4 \%$ paraformaldehyde in $0.1 \mathrm{M}$ sodium phosphate buffer ( $\mathrm{pH}, 7.4$ ), and postfixed for 2 $\mathrm{hr}$ in situ. The brains were cryoprotected in $30 \%$ sucrose and sectioned on a cryostat at $10 \mu \mathrm{m}$ in the coronal plane. Sections were mounted on gelatin and poly-L-lysine coated slides. LAMP localization was performed using fluorescein- and HRP-conjugated secondary antibodies (Levitt, 1984). Sections were washed twice in $0.1 \mathrm{~m}$ sodium phosphatebuffered saline (PBS; pH, 7.4) and incubated for $30 \mathrm{~min}$ in $4 \%$ Carnation dry milk in PBS (BLOTTO). Sections were then incubated for $18 \mathrm{hr}$ at room temperature in anti-LAMP monoclonal antibody (hybridoma clone 2G9) and diluted in BLOTTO (1:35 for immunofluorescence, 1:200 for immunoperoxidase). After 3 washes in BLOTTO, the sections were incubated for $2 \mathrm{hr}$ in fluorescein- or HRP-conjugated goat anti-mouse IgG (Jackson ImmunoResearch) diluted 1:50 with BLOTTO. For fluorescence, the sections were rinsed in 3 changes of PBS and coverslipped with $90 \%$ glycerol/PBS. The HRP was visualized using a conventional diaminobenzidine substrate procedure (Zacco et al., 1990). The fastblue-labeled cells and LAMP-immunofluorescent cells were visualized in the same section using epifluorescence optics utilizing Leitz filter cubes (A and I3, respectively); bright-field illumination was used for 

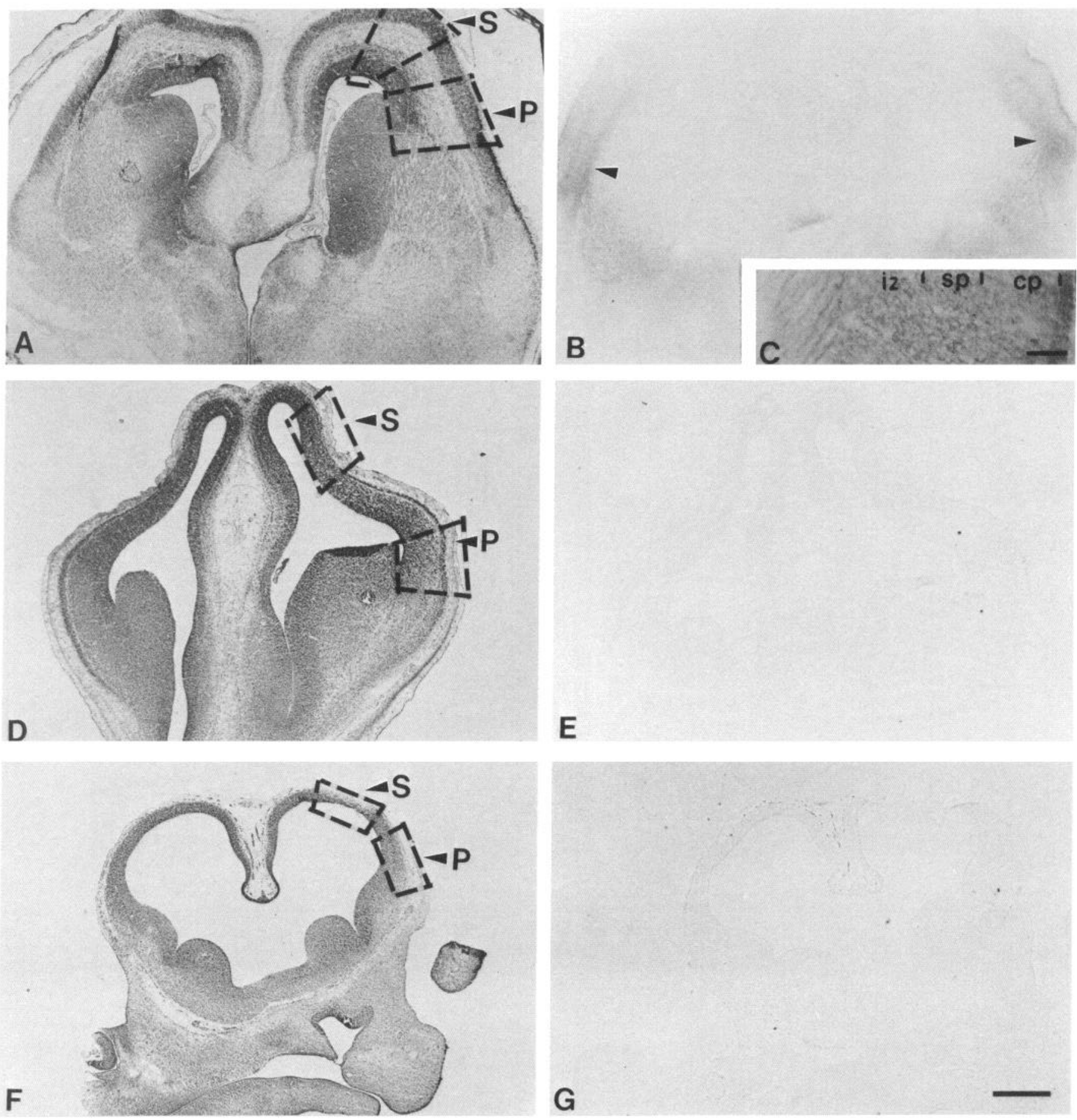

Figure 2. Coronal sections from developing fetal rats illustrating areas of cerebral wall excised for transplantation and appearance of LAMP immunoreactivity. The sections shown are from similar anteroposterior levels rostral to the lamina terminalis and in the region of the developing septum. Perirhinal $(P)$ and sensorimotor $(S)$ areas excised from donor tissue are indicated in cresyl-violet-stained sections $(A, D, F)$ with dashed lines. LAMP immunoreactivity is visualized using HRP-conjugated second antibody $(B, E, G)$. $A$, E17 brain stained with cresyl violet. $B$, LAMP immunoreactivity (arrowheads) in an E17 brain is seen in a section adjacent to that shown in $A$. $C$, Higher-power photomicrograph of perirhinal region depicted in $B$ showing LAMP immunoreactivity in the cortical plate $(c p)$, subplate $(s p)$, and intermediate zone $(i z)$. Scale bar, $90 \mu \mathrm{m}$. $D$, E14 brain stained with cresyl violet. $E$, E14 forebrain does not express LAMP immunoreactivity after immunohistochemistry. $F$, E12 brain stained with cresyl violet. $G$, E12 forebrain does not express LAMP immunoreactivity after immunohistochemistry. Scale bar, $440 \mu \mathrm{m}$ for $A, B$, and $D$ - $G$.

HRP-labeled antibodies. Ilford XP1 ASA 400 film was used for the photography. Some of the sections of each transplant were stained after photography with cresyl violet or hematoxylin and eosin to evaluate integration of donor tissue into host tissue.

Cell counts. Between 800 and 1000 surviving transplanted cells (fast blue labeled) in each brain were counted in photomicrographs that were made using a $63 \times$ objective and printed at a magnification of $500 \times$. The specimens were analyzed for the percent that were double labeled by anti-LAMP (surface immunoreactive). Cells positively labeled for LAMP had bright punctate fluorescent staining pericellularly (see Fig. 4). Staining in the neuropil surrounding the cells was not used as criteria for categorizing a soma as LAMP immunoreactive. By these conser- 

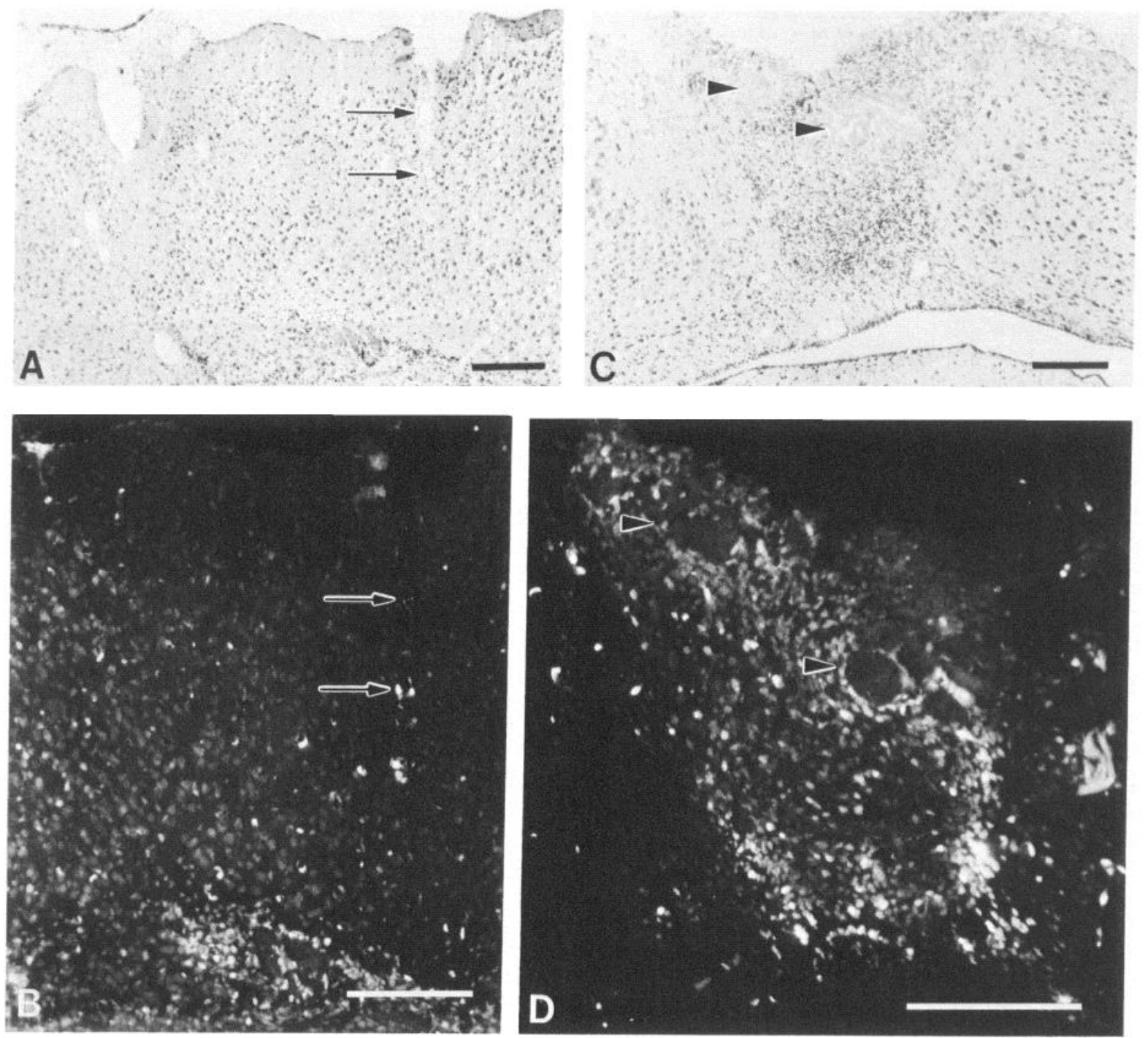

Figure 3. Transplantion site of tissue located heterotopically in host cortex. $A$ and $B$, Bright-field and fluorescence photomicrographs of the same coronal section of host cortex illustrating a transplant of E14 presumptive perirhinal cortex located in the host sensorimotor cortex. $A$, The transplant fills the cavity of the cortical site in an 11-d-old rat. The arrows mark a blood vessel in the transplant. Scale bar, $200 \mu \mathrm{m}$. B, Fast-blue-labeled cells of the transplant in the same section as $A$ viewed under fluorescence illumination with a UV filter. The arrows mark the same blood vessel as in $A$. This blood vessel demarcates the right-hand edge of the transplant. Scale bar, $200 \mu \mathrm{m}$. $C$ and $D$, Bright-field and fluorescence photomicrographs of E14 presumptive sensorimotor cortex transplanted into host perirhinal cortex. $C$, The location of the transplant in the host is shown in this hematoxylin- and eosin-stained section. The arrowheads indicate the presence of avitene in the transplant, which was placed over the tissue slab during transplantation. $D$, Fast-blue-labeled cells of the transplant in a section adjacent to that depicted in $C$. The arrowheads mark avitene seen in $C$. Scale bars, $140 \mu \mathrm{m}$ for $C$ and $D$.

vative criteria, we are probably underestimating the percentage of LAMPpositive cells in the transplants that contain a high concentration of immunostaining in the neuropil. This did not affect the counts in the transplants exhibiting modest to sparse immunoreactivity in the neuropil. Three to 4 sections from each transplant were photographed completely and analyzed in each brain. The fast-blue-labeled cells were divided into 4 categories based on morphology: large neurons with processes, glial cells, endothelial cells, and cells with indistinctive morphology, termed "unclassified." The percentage of cells that were double labeled in each category was calculated. The Mann-Whitney $U$ test was employed to compare differences between experimental groups.

\section{Results}

\section{Cortical transplants}

The fetal tissue used for transplantation was dissected from the cerebral wall in regions corresponding to presumptive sensorimotor and perirhinal cortices (Figs. 1,2). The presumptive sen- sorimotor regions of the cerebral wall never express LAMP (Horton and Levitt, 1988), whereas perirhinal regions throughout the rostrocaudal extent of the cerebral hemisphere express LAMP beginning at E15. Three ages were selected for transplantation based on the temporal patterns of LAMP expression and neurogenesis. Brains harvested at both E12 and E14 do not express LAMP (Fig. 2), but differ in that neurogenesis has been ongoing in the perirhinal cortex for about $24 \mathrm{hr}$ at E14 in the albino rat (Table 1). Brains harvested at E17 have a larger number of postmitotic neurons. At that age, neurons destined for layers IV-VI have been generated (Hicks and D'Amato, 1968; Raedler et al., 1980; Altman and Bayer, 1990), and neurons in the intermediate zone migrating to the cortical mantle, as well as the first generated neurons in the cortical plate, express LAMP at this time (Table 1, Fig. 2). 
Table 1. Correlation between time of origin of neurons and LAMP expression in rat cerebral cortex

\begin{tabular}{lll} 
Age & Neurogenesis & $\begin{array}{l}\text { Lamp } \\
\text { expression }\end{array}$ \\
\hline E12 & - & - \\
E14 & ++ & - \\
E17 & +++ & ++
\end{tabular}

a Sources: Hicks and D'Amato, 1968; Raedler et al., 1980; Altman and Bayer, 1990.

${ }^{b}$ Source: Horton and Levitt, 1988.

Heterotopic (Fig. 3) and homotopic transplants into P1 host brains integrated well, filling the cavity in the host cortex. In general, the fetal tissue harvested at the earlier ages exhibited a better survival rate, determined by the amount of necrosis as well as longer neuritic extensions as shown by the fast blue labeling. Upon initial histological examination, 51 of the 70 transplants were well integrated. The remaining 19 were rejected because of necrosis. All surviving transplants contained welldifferentiated neurons and substantial neuropil. In all cases, fastblue-labeled cells in each of 4 major morphological categories were observed (Figs. 4-7): (1) cells with neuronlike morphology, including a large apical dendrite; (2) glial cells with small cell bodies and numerous, short processes; (3) endothelial cells lining blood vessels within the transplants; and (4) unclassified cells with indistinct morphologies, including soma diameter of 7-10 $\mu \mathrm{m}$ and few, if any, visible processes. The intensity of fast blue labeling was maintained for the first $18 \mathrm{~d}$ of transplantation, thereafter decreasing dramatically. All animals for quantification were killed at $10-14 \mathrm{~d}$ posttransplantation (P11-15) to ensure adequate labeling of all cell populations. A few animals in each category were killed at $18 \mathrm{~d}$ posttransplantation (P19) and exhibited the identical double-labeling patterns as those killed at P11-15.

\section{Homotopic transplants}

This category of cortical transplants served as controls for LAMP expression; donor tissue from presumptive sensorimotor and perirhinal regions was placed into the appropriate cortical region (homotopic) of neonatal host animals. In no cases at any transplantation age (E12, E14, and E17) were fast-blue-labeled cells in homotopic sensorimotor transplants immunoreactive for LAMP (Figs. $5 A, B ; 6 A, B ; 7 A, B$ ). In contrast, a large number of identifiable, fast-blue-labeled neurons in perirhinal homotopic transplants were LAMP positive (Figs. $5 C, D ; 6 C, D ; 7 C, D$ ). Neither fast-blue-labeled glial cells nor endothelial cells were LAMP positive, an expected result given that LAMP is expressed only by neurons (Levitt, 1984; Levitt et al., 1986; Zacco et al., 1990). Positive neurons exhibited typical punctate, cell-surface-associated immunofluorescence that is characteristic of LAMP staining (Fig. 4). In addition, the neuropil within the transplants proper was intensely stained for LAMP, representing immunoreactivity typically associated with dendritic processes in the maturing cortex (Levitt, 1984; Zacco et al., 1990). The intensity of LAMP immunoreactivity on transplanted perirhinal neurons was comparable to that seen in host brains. The intensity of LAMP staining also appeared to be independent of the age of the donor. Thus, neurons from E12 were as likely to be as intensely immunoreactive as those from E17 transplants. The variability in staining intensity, due to fixation sensitivity, is
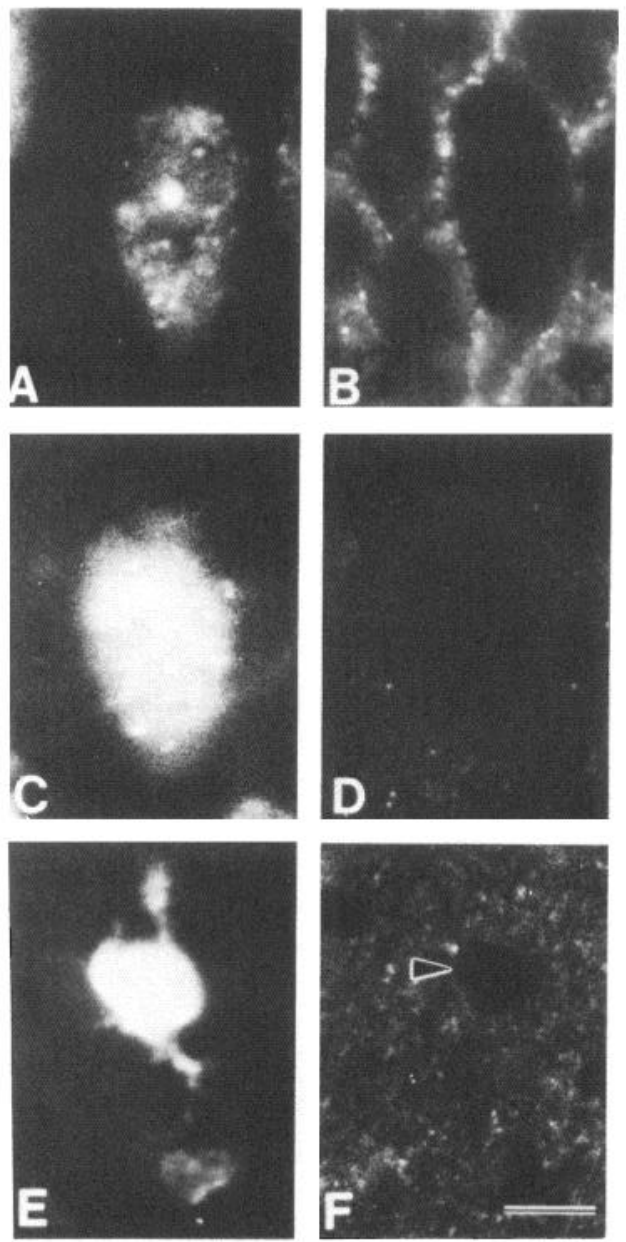

Figure 4. High-power photomicrographs of cells from transplants of E14 presumptive perirhinal area transplanted into $\mathrm{P} 1$ perirhinal host cortex. The host animals were killed $10 \mathrm{~d}$ posttransplantation. A, A neuron demonstrating finely particulate intracellular staining with fast blue. $B$, Same neuron shown in $A$ stained for LAMP immunoreactivity [using fluorescein isothiocyanate (FITC) second antibody]. The cell body shows typical punctate surface-associated LAMP immunoreactivity. $C$, A different fast-blue-labeled neuron than that shown in $A$. $D$, Same neuron shown in $C$ stained with anti-LAMP monoclonal antibody. No surface-associated LAMP immunoreactivity is seen. Some LAMP immunoreactivity in the neuropil around the cell can be visualized, but there is no clear cell-surface staining around the neuron's cell body. This cell was classified as LAMP negative. $E$, A glial cell labeled with fast blue, demonstrating bright cytoplasmic staining of the cell body and short processes. $F$, Same glial cell (arrowhead) shown in $E$ visualized under FITC optics after LAMP staining. Although diffuse staining of the neuropil is seen, no surface-associated LAMP immunoreactivity (visualized with FITC second antibody) is seen at the location of the fast-blue-labeled glial cell. Scale bar, $15 \mu \mathrm{m}$.

similar to that obtained in normal brains (Levitt, 1984; Zacco et al., 1990).

\section{Heterotopic transplants}

Transplants of presumptive sensorimotor cortex, harvested from E12, E14, or E17 fetuses, integrated well into host brains when placed into cavities within perirhinal cortical regions (Fig. $3 C, D$ ). In the E17 cases examined, fast-blue-labeled sensorimotor neurons never exhibited LAMP immunoreactivity (Fig. $5 G, H$ ). A small number of neurons in the E14 sensorimotor transplants were LAMP immunoreactive (see Fig. 9 and below). In both 
cases, the neuropil did not exhibit any immunoreactivity. In contrast to the sensorimotor heterotopic transplants, both the E14 and the E17 perirhinal transplants, placed in the sensorimotor regions of host brains, contained large numbers of LAMPpositive neurons (Figs. $5 E, F ; 6 E, F)$. These cells exhibited dense LAMP immunoreactivity and were indistinguishable in staining intensity or distribution from either normal or homotopically transplanted perirhinal neurons. The neuropil in the perirhinal heterotopic transplants also exhibited dense LAMP immunoreactivity. As expected, neither glial cells nor endothelial cells labeled with fast blue were LAMP positive in any of the heterotopic transplants examined.

Analysis of the E12 heterotopic transplants revealed a striking difference compared to donor tissue from E14 and E17 cortex; neurons in the E12 donor tissue expressed LAMP in a hostdependent fashion. Thus, in all the E1 2 cases examined, a large number of fast-blue-labeled sensorimotor neurons transplanted into the perirhinal cortex exhibited LAMP immunoreactivity (Fig. $7 G, H)$. Both cells and neuropil in the sensorimotor heterotopic transplants were intensely LAMP immunoreactive (Fig. $7 \mathrm{H}$ ). On the other hand, E12 fast-blue-labeled perirhinal neurons, transplanted heterotopically into sensorimotor areas, never exhibited LAMP immunoreactivity (Fig. $7 E, F$ ). In a corresponding fashion, the neuropil in these transplants also was not stained. In addition, glial cells and endothelial cells labeled for fast blue were not LAMP positive in any of the heterotopic transplants.

\section{Quantification of double-labeled cells in transplants}

We quantified the dramatic differences in LAMP cxpression between sensorimotor and perirhinal transplants, and between the different ages transplanted, by calculating the percentage of fast-blue-labeled cells in each preparation (see description above) that also expressed LAMP immunoreactivity along their cell somata (Figs. 8-10). The results are expressed relative to the total number of fast-blue-labeled cells of each morphological class. In all transplant combinations, glial and endothelial cells never expressed LAMP staining (0\%).

Homotopic transplants. LAMP expression was observed in only $0-0.4 \%$ of the sensorimotor neurons and $0-0.3 \%$ of the cells in the unclassified category of homotopic transplants (Figs. 8-10; E17, E14, and E12, respectively). In contrast, homotopic transplants of perirhinal regions contained approximately 52$70 \%$ double-labeled neurons and $35-49 \%$ double-labeled unclassified cells. Therefore, presumptive perirhinal cortical cells maintain their ability to express LAMP after transplantation homotopically, and presumptive sensorimotor cortical cells are not induced to express LAMP by the surgical procedure.

Heterotopic transplants. Heterotopic sensorimotor transplants from E17 fetuses contained $1.5 \%$ double-labeled neurons and $0.4 \%$ double-labeled unclassified cells (Fig. 8), whereas approximately $3 \%$ of the fast-blue-labeled neurons and $1 \%$ of the unclassified cells were LAMP positive in the E14 sensorimotor heterotopic transplants (Fig. 9). Heterotopic perirhinal trans-

Figure 5. Fluorescence micrographs of sections from homotopic $(A-D)$ and heterotopic $(E-H)$ transplants from E17 donor rats labeled with fast blue. The tissue was processed when hosts were P11 and stained with anti-LAMP using FITC-conjugated second antibody. $A$ and $B$, Presumptive sensorimotor area of the cerebral wall, labeled with fast blue $(A)$ and transplanted homotopically into sensorimotor cortex, fails to exhibit LAMP immunoreactivity $(B)$. $C$ and $D$, Presumptive perirhinal area of the cerebral wall transplanted homotopically into perirhinal cortex contains fastblue-labeled cells $(C)$ that exhibit bright, punctate LAMP immunoreactivity on their surfaces and in the neuropil $(D)$. $E$ and $F$, Presumptive perirhinal area of the cerebral wall labeled with fast blue $(E)$ and transplanted heterotopically into the sensorimotor cortex contains dense LAMP immunoreactivity around neurons and in the neuropil. $G$ and $H$. Presumptive sensorimotor area of the cerebral wall labeled with fast blue $(G)$ and transplanted heterotopically into the perirhinal cortex does not contain LAMP-stained cells or processes $(H)$. Note that, in all cases, the transplanted cells labeled for LAMP are either neurons $(N)$ or unclassified cells $(U)$. Endothelial cells $(E)$ and glia do not express LAMP. The arrowheads indicate representative double-labeled cells. Examples of the same cell classes that are not immunoreactive or LAMP in the sensorimotor transplants are marked with small white arrows. Scale bar, $40 \mu \mathrm{m}$.

Figure 6. Fluorescence micrographs showing sections of homotopic $(A-D)$ and heterotopic $(E-H)$ transplants labeled with fast blue from E14 donor rats. The brains were processed when hosts were P11 and stained with anti-LAMP using FITC-conjugated second antibody. $A$ and $B$, Presumptive sensorimotor area of the cerebral wall labeled with fast blue $(A)$ and transplanted homotopically into the sensorimotor cortex does not contain any LAMP-positive cells $(B) . C$ and $D$, Presumptive perirhinal area of the cerebral wall labeled with fast blue $(C)$ and transplanted homotopically into the perirhinal cortex exhibits LAMP immunoreactivity on the surface of cells and in the neuropil $(D)$. $E$ and $F$, Presumptive perirhinal area of the cerebral wall labeled with fast blue $(E)$ and transplanted heterotopically into the sensorimotor cortex is densely immunoreactive for LAMP $(F) . G$ and $H$, Presumptive sensorimotor area of the cerebral wall labeled with fast blue $(G)$ and transplanted heterotopically into perirhinal cortex does not contain any LAMP-positive cells $(H)$. As in the E17 transplants, the cells double labeled for LAMP are either neurons $(N)$ or unclassified cells $(U)$. Endothelial cells $(E)$ and glia do not express LAMP. The arrowheads indicate examples of double-labeled cells. The arrows denote examples of cells that are not immunoreactive for LAMP. Scale bar, $50 \mu \mathrm{m}$.

Figure 7. Fluorescence micrographs showing sections of homotopic $(A-D)$ and heterotopic $(E-H)$ transplants from E12 donor rats labeled with fast blue. Brains were collected when hosts were P10, sectioned, and stained with anti-LAMP using FITC-conjugated second antibody. $A$ and $B$, As expected, presumptive sensorimotor area of the cerebral wall labeled with fast blue $(A)$ and transplanted homotopically into sensorimotor cortex does not exhibit any LAMP-positive cells $(B) . C$ and $D$, Presumptive perirhinal areas of the cerebral wall labeled with fast blue $(C)$ and transplanted homotopically into perirhinal cortex contains bright, punctate LAMP immunoreactivity on the surface of cells and in the neuropil ( $D$ ). $E$ and $F$, In contrast to E17 and E14 tissue, E12 presumptive perirhinal areas of the cerebral wall labeled with fast blue $(E)$ and transplanted heterotopically into the sensorimotor cortex do not contain any LAMP-positive cells. $G$ and $H$, Presumptive sensorimotor areas of the cerebral wall labeled with fast blue $(G)$ and transplanted heterotopically into the perirhinal cortex exhibit dense, punctate pericellular LAMP immunoreactivity along many cell somata and throughout the neuropil $(H)$. As in the older transplanted tissue, only the neurons $(N)$ or the unclassified cells $(U)$ are double labeled for LAMP. The arrowheads indicate representative double-labeled cells. The arrows mark examples of cells that are not immunoreactive for LAMP. In $C$, one cxample of a glial ccll is shown $(G)$. The glial cell is LAMP negative, though this is not clear unless viewed under higher magnification, such as in Figure 4. In $E$, one example of an endothelial cell is shown. The endothelial cell is LAMP negative. Scale bar, $50 \mu \mathrm{m}$. 

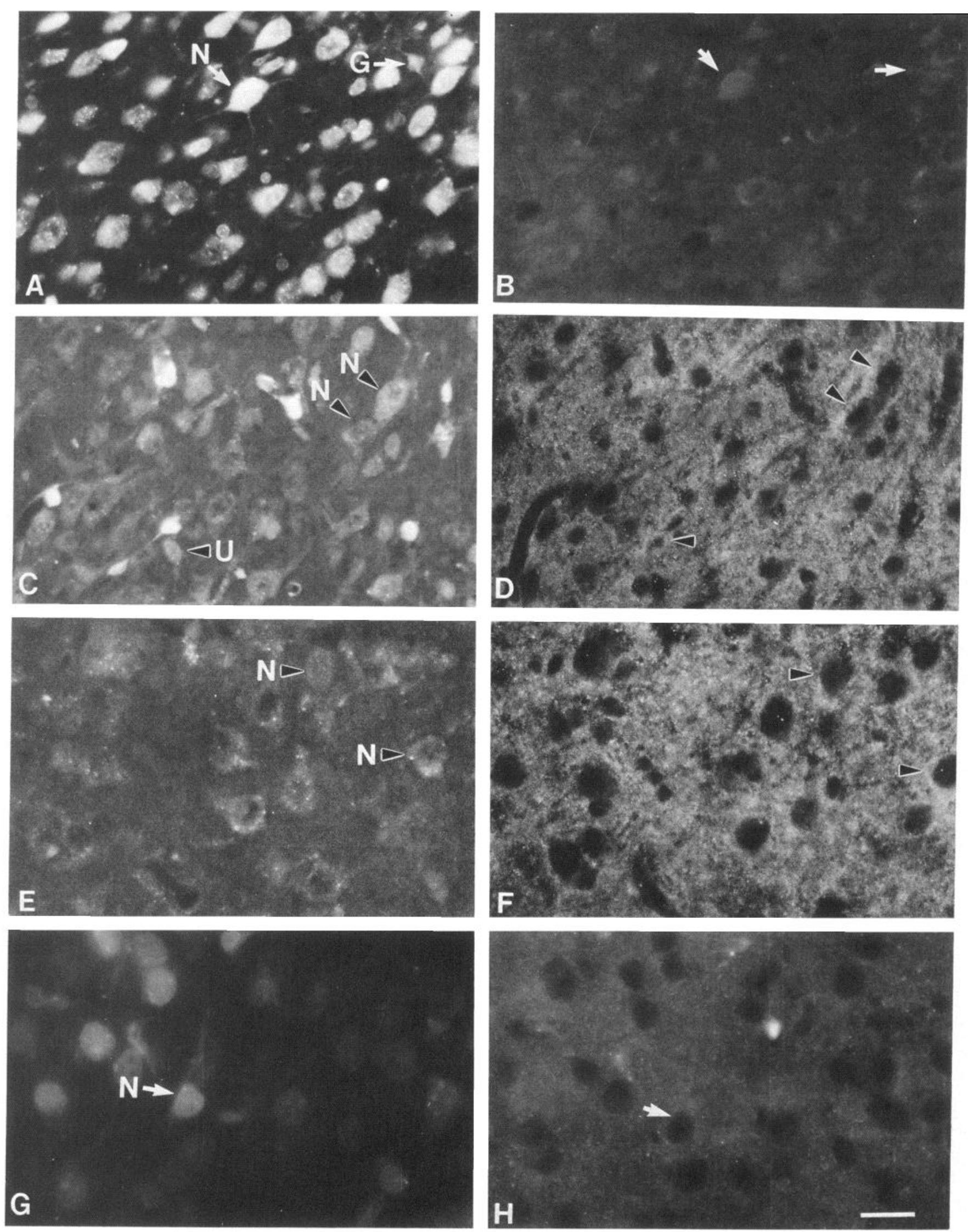

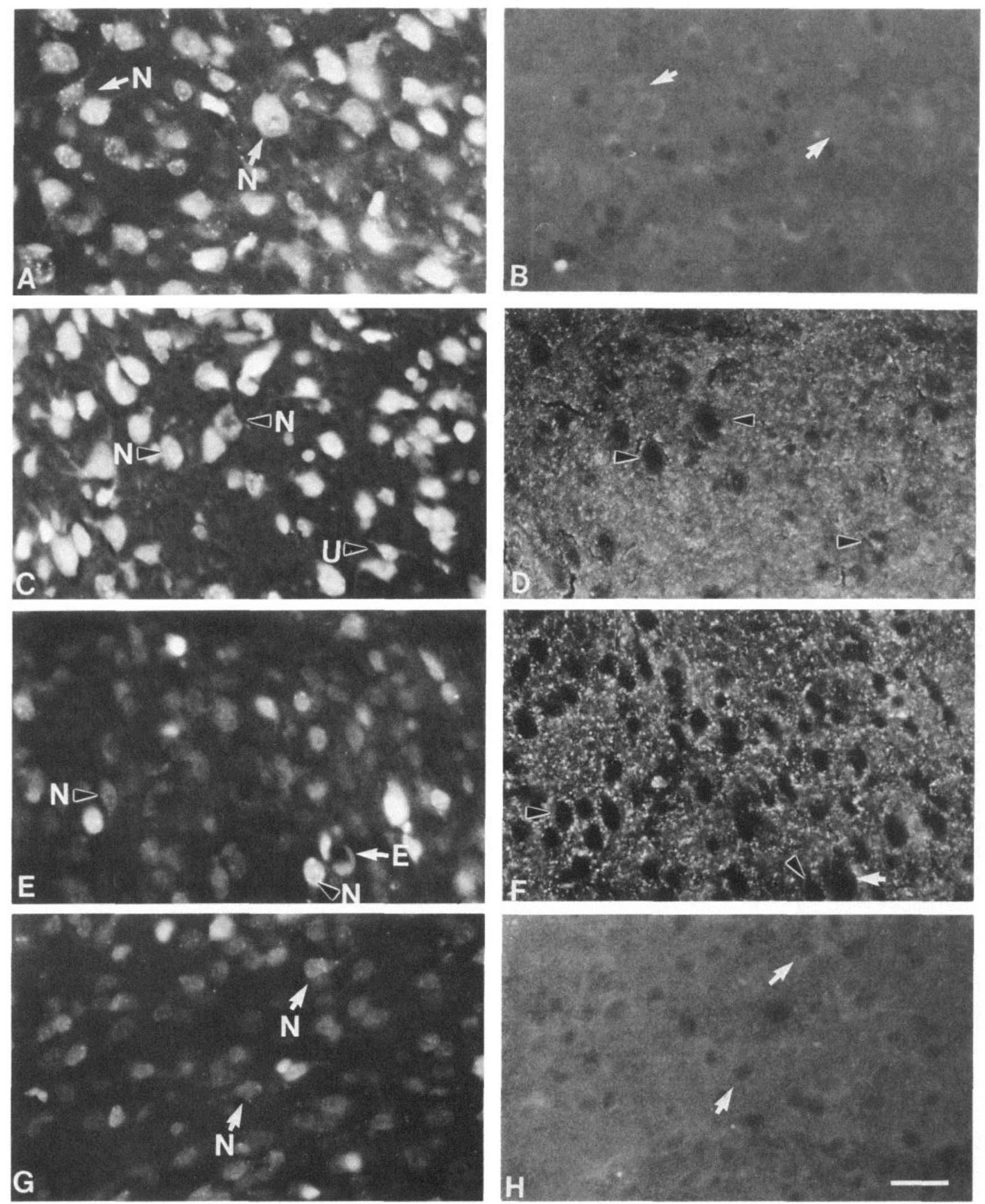

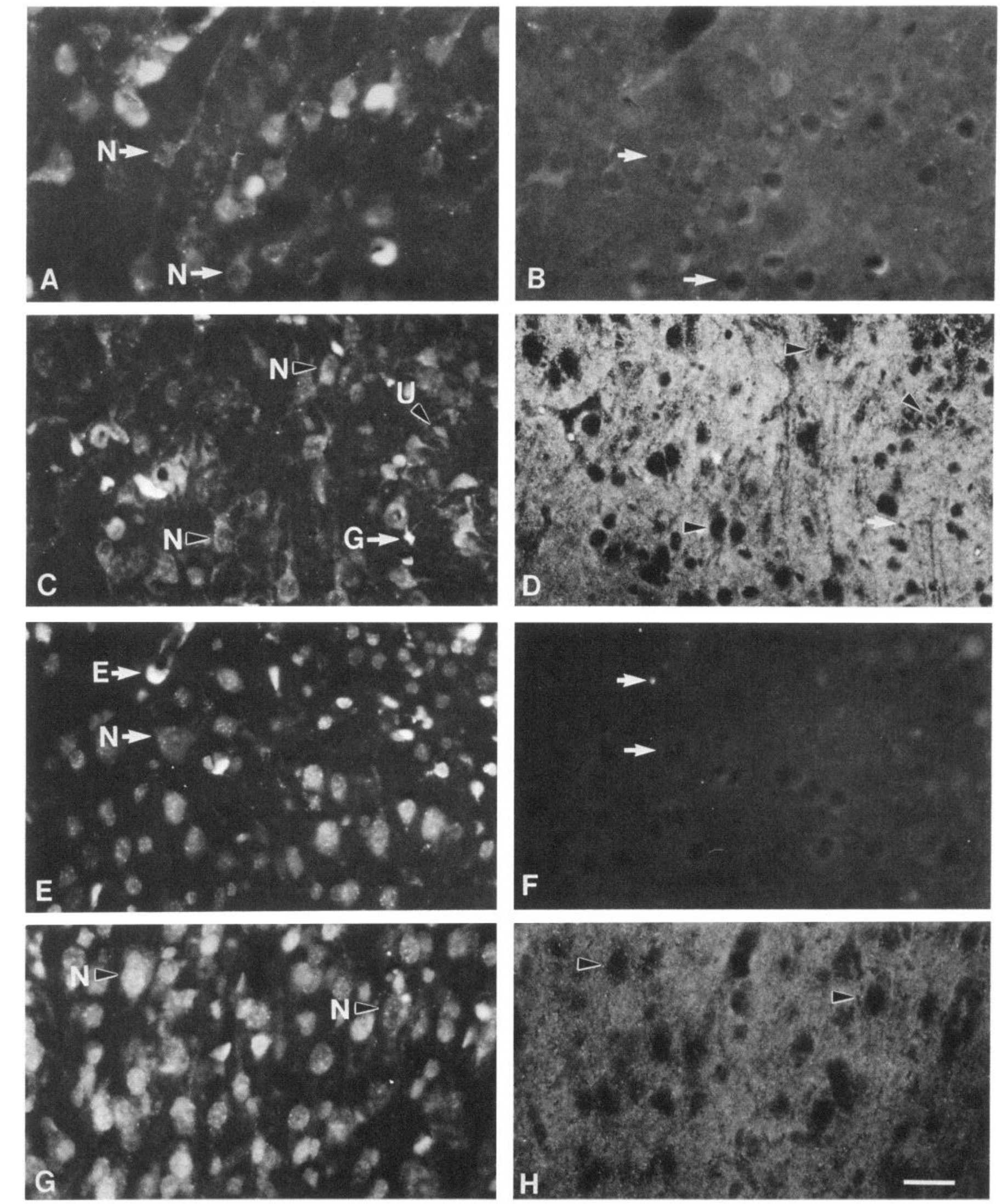
Figure 8. Histogram representing quantification of results of transplantation experiments. Approximately 800-1000 surviving transplanted cells (fast blue) and those double labeled for fast blue and LAMP were counted in each animal. The mean percent of cells double labeled for LAMP and fast blue is represented. At $\mathrm{E} 17$, almost $70 \%$ of the perirhinal neurons, whether transplanted into a homotopic or heterotopic region of cortex, express LAMP. Approximately $25-35 \%$ of the unclassified cells from perirhinal regions of the donors also express LAMP in either combination. Note that only $1.5 \%$ of the sensorimotor cells transplanted heterotypically express LAMP. Solid bars denote perirhinal donor tissues; hatched bars denote sensorimotor tissue. Five animals were quantified per transplant group. Thin vertical bars represent SEM.

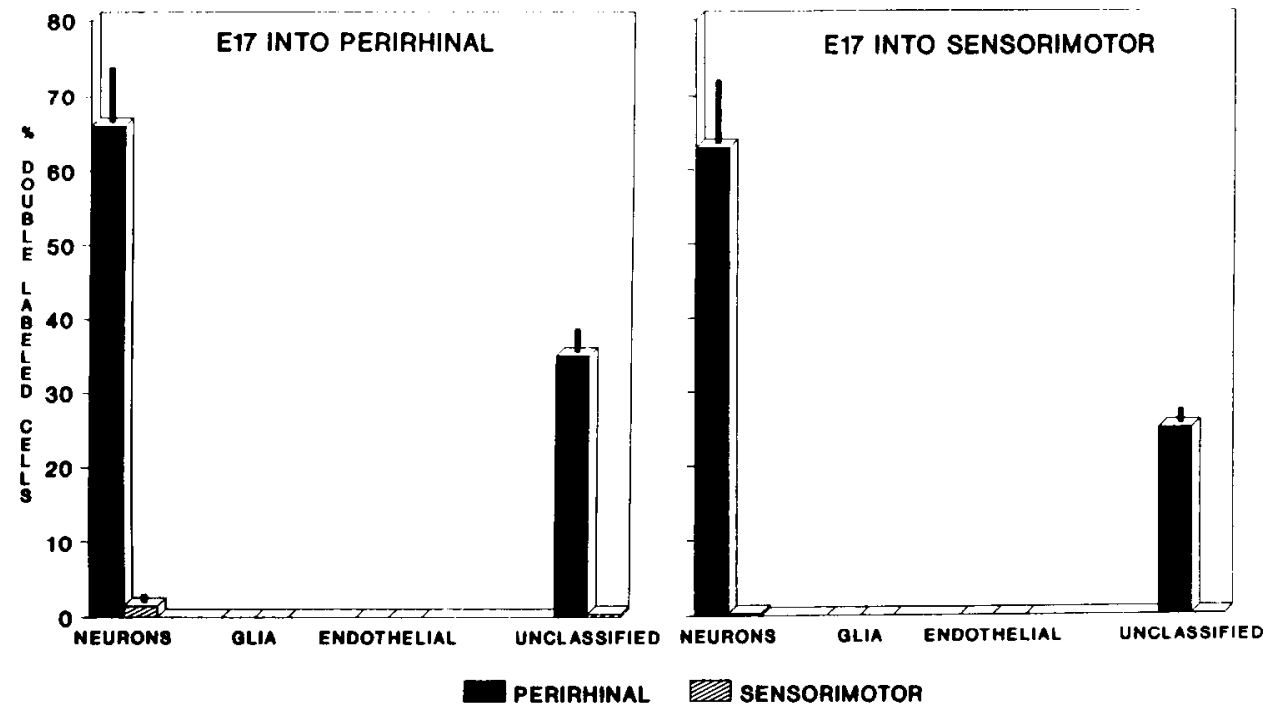

from E14 and E17. The heterotopic transplants harvested from E12 perirhinal cortex contained $0 \%$ double-labeled neurons or unclassified cells (Fig. 9). In summary, E12 presumptive sensorimotor cells, instead of maintaining their original molecular phenotype, express LAMP when transplanted heterotopically into a limbic cortical environment, while E12 presumptive perirhinal cells never express LAMP when transplanted heterotopically into a nonlimbic cortical region of the host.

\section{Discussion}

The present study has used a molecular marker of regions of the limbic system, LAMP, in combination with transplantation of fetal tissue to determine the developmental age at which different cerebral cortical regions become committed to a limbic or nonlimbic phenotype. The results, summarized in Figure 11, demonstrate that neuronal expression of LAMP is faithful to the original presumptive limbic components rather than the transplanted site of development if the transplantation takes place at or later than E14. This result is temporally coincident
Figure 9. Histogram representing quantification of results of transplantation experiments. Approximately $800-1000$ surviving transplanted cells (fast blue) and those double labeled for fast blue and LAMP were counted in each animal. The mean percent of cells double labeled for LAMP and fast blue is represented. Perirhinal tissue from E14 has a significantly higher percentage of double-labeled cells than the sensorimotor cortex, in either homotopic or heterotopic combinations. Approximately $3 \%$ of the sensorimotor cells, when placed into the perirhinal cortex of Pl hosts, are double labeled. The homotopic and heterotopic perirhinal transplants from E17 and E14 donors do not differ from each other statistically $(p>0.15)$. Solid bars denote perirhinal donor tissue; hatched bars denote sensorimotor tissue. Four animals were quantified per transplant group. Thin vertical bars represent SEM.

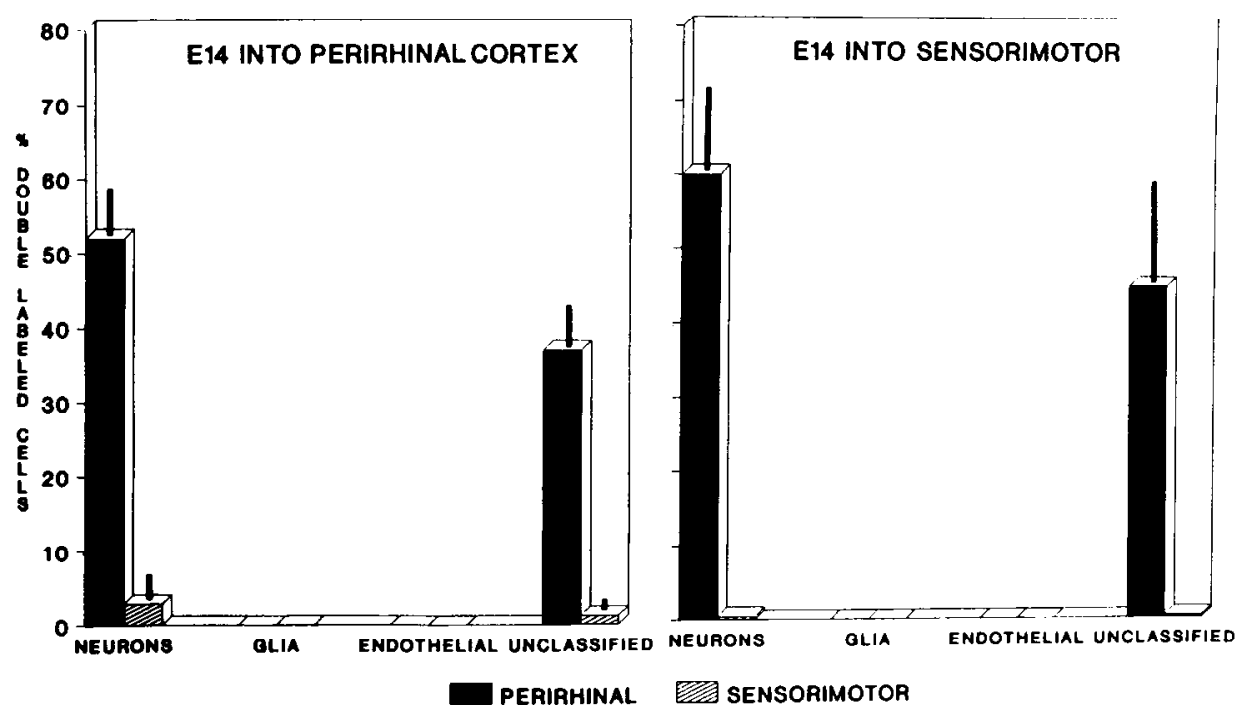



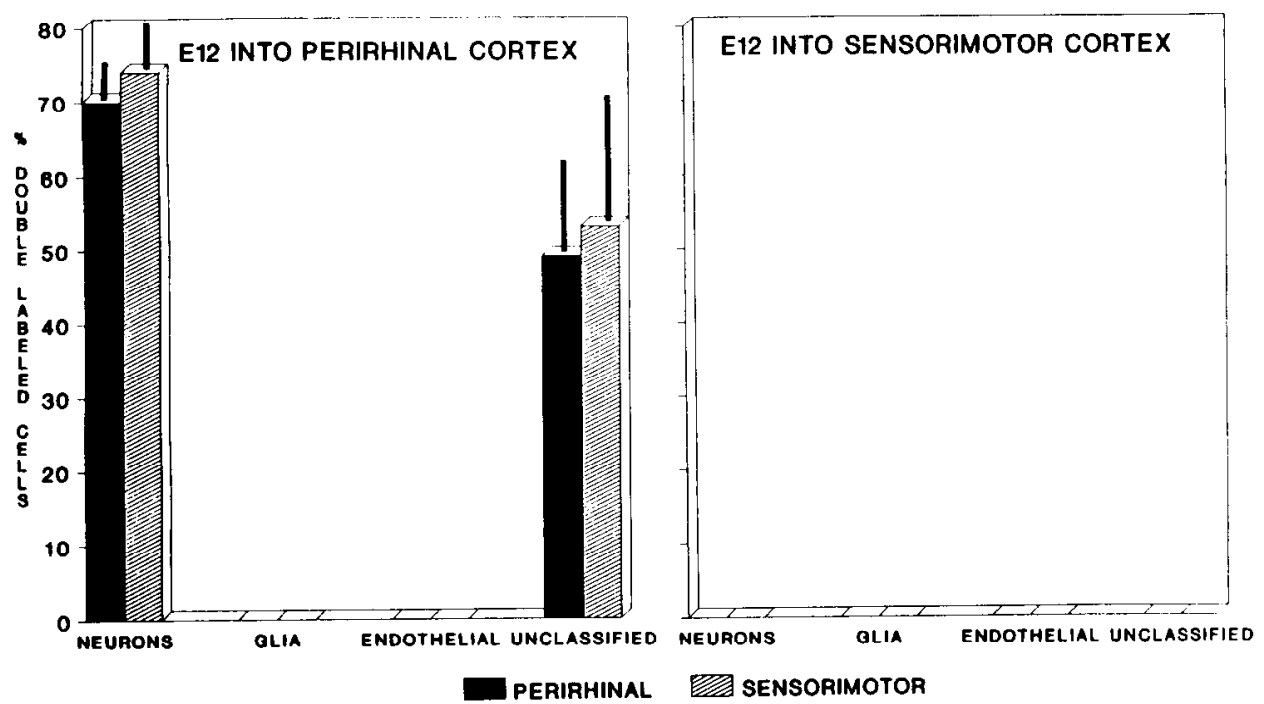

Figure 10. Histogram representing quantification of results of transplantation experiments. Approximately $800-1000$ surviving transplanted cells (fast blue) and those double labeled for fast blue and LAMP were counted in each animal. The mean percent of cells double labeled for LAMP and fast bluc is represented. Perirhinal tissue harvested at E12 and transplanted heterotopically into sensorimotor areas of hosts never contained any double-labeled cells $(0 \%)$. In contrast, the heterotopic sensorimotor transplants contain $74 \%$ double-labeled neurons. This is significantly greater compared to the values obtained with heterotopic transplants of presumptive perirhinal cortex at E14 $(p<0.04)$ and E17 ( $p<0.03)$. As expected the perirhinal transplants into the homotopic cortex also contain a high percentage of LAMP-positive cells. In all cases, endothelial cells and glial cells never express LAMP. Solid bars denote perirhinal donor tissue; hatched bars denote sensorimotor tissue. Four animals were quantified per transplant group. Thin vertical bars represent SEM.

with the onset of neurogenesis. Transplantation of presumptive limbic tissue at E12, prior to neurogenesis, results in the tissue acquiring the phenotypic qualities of the transplantation site in the host rather than the donor region. This suggests that the fate of cerebral hemisphere neurons to express the limbic cortical phenotype becomes restricted early in development, that is, between E12 and E14. Because the first cortical neurons are just arriving at the lateral cortical plate at E15-16 (Berry et al., 1964;
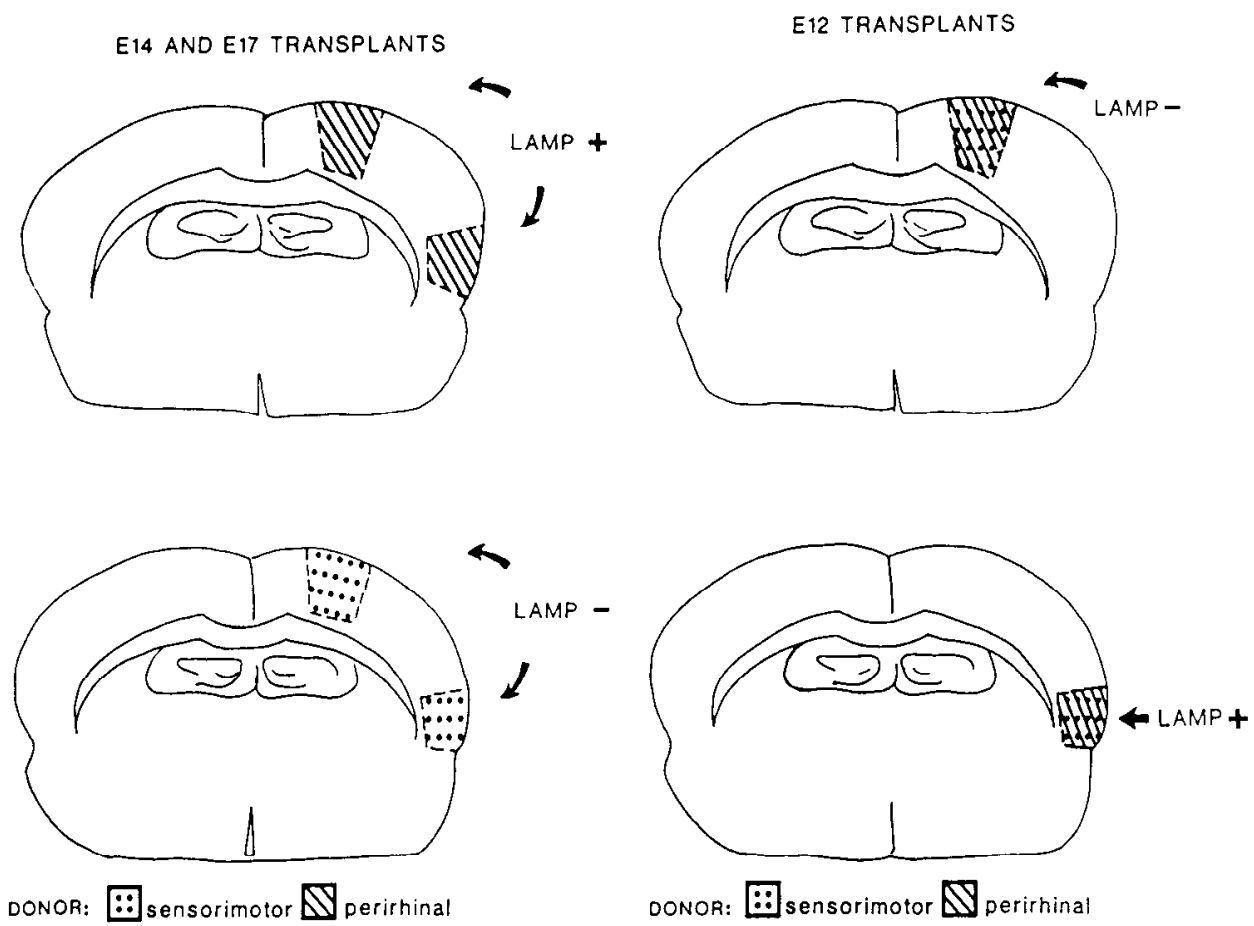

DONOR: : sensorimotor $\$$ perirhinal
DONOR: $:]_{\text {sensorimotor }} \nabla_{\text {perirhinal }}$
Figure 11. Schematic diagram summarizing transplantation results. Both E14 and E17 presumptive perirhinal cortical cells, whether transplanted into the sensorimotor cortex or the perirhinal cortex, exhibit a restricted limbic fate, demonstrated by their ability to express immunodetectable levels of LAMP. Both E14 and E17 presumptive sensorimotor cortical cells never (or rarely) produce LAMP, even when transplanted into the perirhinal cortex, an environment that normally contains LAMP-immunoreactive neurons. This donor faithfulness is age dependent. E12 presumptive perirhinal cortical cells, when transplanted homotopically, express LAMP, but if transplanted heterotopically, show phenotypic regulation in response to their host environment and thus do not express LAMP. This host regulation also occurs with presumptive sensorimotor cells at E12. When they are transplanted into the host perirhinal cortex, the E1 2 presumptive sensorimotor cells assume the molecular phenotype of the surrounding tissue and express LAMP. As expected, presumptive sensorimotor donor tissue from E12 does not express LAMP when placed in its homotopic environment. Hatching represents donor tissues; dots represent sensorimotor donor tissue. 
Bcrry and Rogers, 1965; Hicks and D'Amato, 1968; Bruckner et al., 1974), the commitment to a limbic phenotype must occur prior to their arrival in the cortical plate.

\section{Characteristics used to define phenotype}

The phenotype of a cell may be defined in a variety of ways, using morphological characteristics such as cell shape, type of processes, and projection patterns, or molecular features such as neurotransmitters, neuropeptides, synthetic enzymes, and specific cell-surface molecules and receptors. Each of these characteristics appears to be subject to manipulation through changes in local cues presented to cells in their environment, though the extent of alteration may vary greatly. For example, neuronal precursor cells can be isolated in culture, undergo mitotic division, and maintain the capacity to express normal phenotypic shapes and patterns of process growth (Fischbach, 1970; Banker and Cowan, 1977; Waxman et al., 1977; Kriegstein and Dichter, 1983; Mattson et al., 1988a,b). Glial precursor cells exhibit striking regulation of their fate based on specific factors provided in their growth environment in vitro (Raff et al., 1985; Levine and Stallcup, 1987; McMorris and Dubois-Dalcq, 1988; Miller et al., 1989; Lillien and Raff, 1990). Specific classes of normally developing neurons may produce transient projections that undergo stereotypical elimination based on environmental interactions (Ivy et al., 1979; Innocenti and Caminiti, 1980; Innocenti, 1981; McLoon et al., 1982; O'Leary et al., 1983; Thanos et al., 1984; Stanfield and O'Leary, 1985). Phenotype based on neurotransmitter expression also appears to be defined by manipulation of local cues (Anderson and Michelsohn, 1989; Denis-Donini, 1989; Ehrlich et al., 1989; Morris and Gibbins, 1989; Notter et al., 1989). For example, adrenergic and cholinergic characteristics can be expressed by sympathetic neurons, depending upon cell culture conditions (Patterson and Chun, 1977; Landis, 1980; Potter et al., 1986) or peripheral target interactions (Landis et al., 1987; Stevens and Landis, 1990).

There are few studies that have examined regulation of expression of molecules that are shared by developing neurons comprising functional circuits. This phenotypic classification is relatively recent, based on identification of unique macromolecules using technical advances in immunology and molecular biology (Levitt, 1985; Valentino and Reichardt, 1985; Yamamoto et al., 1985; Barnstable, 1987; von der Weid and Zurn, 1990). Nonetheless, there is some recent evidence that developmental expression of anatomically restricted cell-surface proteins can be affected substantially by local cues within the environment. CAT-301, a proteoglycan expressed in regions of the mammalian CNS (Hendry et al., 1984; Zaremba et al., 1989), appears to require specific cellular interactions during a critical period of development for normal expression to occur (Kalb and Hockfield, 1988, 1990; Sur et al., 1988). The expression of cell adhesion molecules, such as NCAM, turns on and off during specific periods of development. For example, neural crest cells only express NCAM prior to and just after migration occurs (Thierry et al., 1982, 1985).

\section{Suitability of LAMP as a phenotypic marker in transplants}

While several proteins marking specific neuronal circuits in the invertebrate nervous system have been identified, few such proteins are known for the vertebrate CNS. Recently, LAMP was isolated and found to be expressed by neurons residing in cortical and subcortical limbic regions of the early developing and mature vertebrate brain (Levitt, 1984; Levitt et al., 1986; Hor- ton and Levitt, 1988; Zacco et al., 1990). LAMP is never expressed, even transiently, by neurons in nonlimbic cellular areas. This membrane glycoprotein appears to be a critical component in the formation of circuits in parts of the limbic system (Keller et al., 1989). The expression of LAMP by neurons is maintained under conditions of partial deafferentation (Keller and Levitt, 1989; H. L. Horton and P. Levitt, unpublished observations). Each of these features contributes to the suitability of LAMP as a marker of limbic phenotype.

LAMP is currently the only marker of a particular cytoarchitectonically defined region of the cerebral cortex in the rat. LAMP does not label differentially individual neuronal phenotypes within a given area and thus serves to identify all neuronal populations in a limbic region (Zacco et al., 1990). In this sense, LAMP can be used to identify the fate, or phenotype, of any individual limbic neuron in the cerebral cortex. The results we obtained by quantitatively analyzing tissue $10 \mathrm{~d}$ posttransplantation, when transplanted neurons could still be identified by fast blue, were also evident in animals killed as late as $18 \mathrm{~d}$ after surgery. Turnover of membrane proteins usually ranges from rapid times of just a few hours to very slow times of a few days (Ruegg et al., 1989). It is unlikely, then, that the labeling of the transplants from E14 and E17 donors reflects abnormally slow protein turnover, which could theoretically contribute to the maintenance of LAMP in cells that will otherwise lose their ability to express LAMP in heterotopic locations. In addition, the E12 and E14 tissue does not contain any LAMP-immunoreactive cells prior to transplantation. This indicates that initiation of LAMP synthesis must occur in situ after transplantation. This would appear to be the most likely case, because a high percentage of neurons ( $74 \%$ at E12, $60 \%$ at E14) in the transplant are LAMP positive, and the intensity of immunoreactivity along somata and in the developing neuropil reflects the typical in vivo pattern of increased staining during development.

\section{Comparison to other studies manipulating the local cortical environment}

The expression of restricted phenotypic fate by cells of the cerebral hemisphere, represented by development of characteristics of a particular cortical area or layer, has been examined extensively using a variety of paradigms. Projection patterns have been observed in neurons situated in aberrant locations. Ionizing radiation causes corticospinal neurons to migrate abnormally to form ectopic neuronal clusters in subcortical white matter and supragranular layers, yet these cells were found to project to appropriate targets (Jensen and Killackey, 1984), suggesting that final radial position within the cerebral cortex is not critical for determining subcortical projection patterns. This is also evident from studies in the reeler mutant mouse, which exhibits an inverted lamination pattern in the cerebral cortex, yet has relatively normal projection patterns subcortically (Steindler and Colwell, 1976; Caviness and Rakic, 1978; Simmons et al., 1982; (aviness and Pearlman, 1984). In contrast, the tangential position of neurons in the cerebral hemisphere is an important feature in defining specific projection patterns. This has been documented in the most complete set of transplant studies performed thus far, in which Stanfield and O'Leary (1985) and O'Leary and Stanfield (1989) found that fetal neocortical neurons, obtained from either visual or motor areas, exhibited subcortical projection patterns that were appropriate for their new environment in the host. This suggests that subcortically 
projecting neurons, residing mostly in layer $\mathrm{V}$, may be identical throughout different neocortical areas during a critical period of development (O'Leary, 1989) and thus would depend upon specific extrinsic cues to express an appropriate phenotype. Because all layer $\mathrm{V}$ neurons normally exhibit similar developmental projection patterns, the transplantation data may reflect the cellular interactions that are required to stabilize (or retract) specific fiber projections. The effects of changing these cellular interactions, such as altering thalamic afferent input, may also result in modifying intrinsic microcircuitry of the neocortex (Sur et al., 1990). Recent experiments, using barrel-field organization as a marker of somatosensory cortical phenotype, also indicate that the cellular organization of the neocortex may indeed be determined late in development and requires significant environmental interactions (Schlagger and O'Leary, 1989).

The present study differs from those noted above; we have used a molecular marker to assess cortical areal phenotype. This is an important distinction because LAMP expression may be a more immutable phenotypic feature than projection patterns of neurons. This is evident from both the meso- and the neocortical transplants, because in both instances, their fates, determined by LAMP expression, were restricted rather early in fetal development. In addition, we have directly compared the fate of the limbic cortex with the neocortex in our transplantation paradigm. This distinction also may be significant, because it is possible that the fate of phylogenetically older cortex, such as the allocortex proper (hippocampus) or mesocortex (perirhinal), is less capable of exhibiting developmental plasticity. The regulation of the fate of the limbic cortex may relate to the relatively minor phylogenetic organizational changes that are exhibited by these regions of the cortex compared to the true, 6-layered neocortex (discussed in O'Leary, 1989). In addition, because we are using a marker of meso/allo cortex, it is possible that the restricted plasticity of LAMP expression reflects this rather conservative development of the limbic cortex phylogenetically. If a marker of a particular neocortical area were available, we might not find its expression to be so rigidly controlled in early fetal development. In support of this concept, our recent study, in which the afferent and efferent projections of transplants were analyzed, indicates that the limbic cortex is capable of developing normal connections, even when located in heterotopic regions (Barbe and Levitt, 1990).

\section{Mechanisms regulating cortical fate}

There are diverging opinions concerning the mechanisms that govern the commitment of precursor cells to cytoarchitectonically distinct cerebral cortical areas. 'The present findings do not allow us to distinguish between models invoking interactions with extrinsic fiber systems and thosc in which signals intrinsic to a cell or topographically (and perhaps clonally) related groups of cells modulate phenotypic fate. An early, restricted developmental fate of the cerebral cortex, however, is supported by the present study in which LAMP expression occurs only in those populations of neurons originally destined to comprise the limbic cortex, irrespective of their new location. This occurs only in tissue transplanted at E14 or later. If transplanted at E12, the donor cortex fails to develop limbic characteristics. This may be due to the reported lack of thalamic afferents growing into the cortex at the time of tissue harvesting at E12 (Lund and Mustardi, 1977; Wolff et al., 1979). It is evident from examination of normal material that the internal capsule forms at E13 in the albino rat, and that these fibers first enter the cerebral wall in the lateral hemisphere between E13 and E14 (M. F. Barbe and $P$. Levitt, unpublished observations using neurofilament staining). At E14 and E17, migrating neurons have reached the intermediate and subplate zones, where thalamic fibers reside during a quiescent period of development (Berry and Rogers, 1965; Smart and Smart, 1977; Wise and Jones, 1978; Crandall and Caviness, 1984) and thus could affect the differentiation of presumptive limbic neurons at these ages, where we showed an immutable limbic fate. Clearly, cortical afferents play a crucial role in pattern formation, illustrated most convincingly in the barrel fields of the somatosensory cortex in the rodent (Woolsey and Van der Loos, 1970; Cooper and Steindler, 1989).

An alternative explanation invokes a mechanism in which the restriction of the options of phenotypic expression is linked to stem cells becoming postmitotic. This, however, does not necessarily presume a simple model of intrinsic genetic regulation. There are numerous studies showing that stcm cclls and peripheral neuroblasts are capable of responding dramatically to cues in the local milieu, affecting neurotransmitter phenotype, cytodifferentiation, and even the types of mature cells being generated (Cohen, 1974; Anderson and Axel, 1986; Reh, 1987; Rohrer and Thoenen, 1987; Stemple et al., 1988; Anderson and Michelsohn, 1989; DiCicco-Bloom et al., 1990). At E12, the entire population of presumptive limbic and sensorimotor cells is mitotically active; neurogenesis in the cerebral cortex begins at E13-14 in the albino rat. Thus, the relative plasticity of the cell population at E12, but not at E14 or later, may reflect the commitment to the meso/allocortical phenotype upon exiting the cell cycle and leaving the ventricular zone to begin migration to the cortical plate. In fact, the first expression of LAMP immunoreactivity in the cerebral wall is by migrating cells situated in the intermediate zone at E15 (Horton and Levitt, 1988). The initial timing of commitment may be carlier than when we are able to detect the protein, as others have found for messenger RNA expression encoding specific proteins (Anderson and Michelsohn, 1989; Lugo, et al., 1989).

The expression of adrenergic phenotype in the CNS is linked to stem cells exiting the cell cycle (Rothman et al., 1980). New data from transplantation studies indicate that the commitment by a cell to a particular laminar fate in the cerebral cortex is an early, cell-cycle-dependent event (McConnell and Kaznowski, 1990; S. McConnell, personal communication). This is consistent with our quantitative data, in which we found a trend for increased numbers of double-labeled cells (though not statistically different) between E14 and E17 heterotopic perirhinal transplants. This suggests that the double-labeled populations might have originated from the pool of transplanted postmitotic cells. The smialler-than-expected increase in the number of doublc-labcled cclls at E17, when there are a larger number of postmitotic cells, may be due to our finding that there is better overall survival of the cells when transplanted at younger ages. We found a significant increase in the number of double-labeled neurons when we compared the sensorimotor heterotopic transplants at E12 with the older perirhinal heterotopic groups. This suggests that the double-labeled population might have originated from a different, but larger, pool of surviving transplanted cells at E12, in this case, the mitotically active precursor cells that comprise the entire donor tissue. This difference in survival also may be reflected in the higher percentage of double-labeled cells in the early perirhinal homotopic transplants compared to the double-labeled cell populations at older ages.

Distinctions between these 2 proposed mechanisms are being 
examined more directly by ${ }^{3} \mathrm{H}$-thymidine labeling of ccll populations in transplanted tissues. Regardless of the mechanism, the present study reveals an early restricted fate of neurons to a particular molecular phenotype, one that reflects the commitment of these cells to comprise distinct cytoarchitectonic (limbic) regions of the cerebral cortex.

\section{References}

Altman J, Bayer SA (1990) Vertical compartmentation and cellular transformation in the germinal matrices of the embyronic rat cerebral cortex. Exp Neurol 107:23-35.

Anderson DJ, Axel R (1986) A bipotential neuroendocrine precursor whose choice of cell fate is determined by NGF and glucocorticoids. Cell 47:1079-1090.

Anderson DJ, Michelsohn A (1989) Role of glucocorticoids in the chromaffin-neuron developmental decision. Int J Dev Neurosci 7 : $475-487$.

Banker GA, Cowan WM (1977) Rat hippocampal neurons in dispersed cell culture. Brain Kes 126:397-425.

Barbe MF, Levitt P (1990) Connectivity of fetal limbic cortex transplanted into non-limbic cortex. Soc Neurosci Abstr 16:1151.

Barnstable CJ (1987) Immunological studies of the diversity and development of the mammalian visual system. Immunol Rev 100:4778.

Berger B, Verney C, Gaspar P, Febvret A (1985) Transient expression of tyrosine hydroxylase immunoreactivity in some neurons of the rat neocortex during postnatal development. Dev Brain Res 23:141-144.

Berry M, Rogers AW (1965) The migration of neuroblasts in the developing cerebral cortex. J Anat 99:691-709.

Berry M, Rogers AW, Eayrs JT (1964) Pattern of cell migration during cortical histogenesis. Nature 203:591-593.

Bloom FE (1984) The functional significance of neurotransmitter diversity. Am J Physiol. 246:184-194.

Boulder Committee (1970) Embryonic vertebrate central nervous system: revised terminology. Anat Rec 166:257-261.

Bruckner G, Vladislav M, Biesold D (1974) Neurogenesis in the visual system of the rat. An autoradiographic investigation. J Comp Neurol 166:245-256.

Caviness VS Jr, Pearlman AL (1984) Mutation-induced disorders of mammalian forebrain development. In: Organizing principals of neural developing (Sharma SC, ed), pp 277-305. New York: Plenum.

Caviness VS Jr, Rakic P (1978) Mechanisms of cortical development: a view from mutations in mice. Annu Rev Neurosci 1:297-326.

Cohen AM (1974) DNA synthesis and cell division in differentiating avian adrenergic neuroblasts. In: Wenner-Gren Center international symposium series, Vol 22, Dynamics of degeneration and growth in neurons (Fuxe K, Olson L, Zotterman Y, eds), pp 359-370. Oxford: Pergamon.

Cooper NG, Steindler DA (1989) Critical period-dependent alterations of the transient body image in rodent cerebral cortex. Brain Res 489:167-176.

Cowan WM, Fawcett JW, O'Leary DDM, Stanfield BB (1984) Regressive events in neurogenesis. Science 225:1258-1265.

Crandall JE, Caviness VS Jr (1984) Thalamocortical connections in newborn mice. J Comp Neurol 228:542-546.

Croucher SJ, Tickle C (1989) Characterization of epithelial domains in the nasal passages of chick embryos: spatial and temporal mapping of a range of extracellular matrix and cell surface molecules during development of the nasal placode. Development 106:493-509.

DeCamilli P, Miller PE, Levitt P, Walter U, Greengard P (1984) Anatomy of cerebellar Purkinje cells in the rat determined by a specific immunohistochemical marker. Neuroscience 11:761-817.

Denis-Donini S (1989) Expression of dopaminergic phenotypes in the mouse olfactory bulb induced by the calcitonin gene-related peptide. Nature 339:702-704.

DiCicco-Bloom E, Townes-Anderson E, Black IB (1990) Neuroblast mitosis in dissociated culture: regulation and relationship to differentiation. J Cell Biol 110:2073-2086.

Dodd J, Sorter D, Jessell TM (1984) Monoclonal antibodies against carbohydrate differentiation antigens identify subsets of primary sensory neurons. Nature 311:469-472.

Ehrlich ME, Evinger JM, Joh TH, Teitelman G (1989) Do glucocorticoids induce adrenergic differentiation in adrenal cells of neural crest origin? Dev Brain Res 50:129-137.
Farbman AI, Margolis FL (1980) Olfactory marker protcin during ontogeny: immunohistochemical localization. Dev Biol 74:205-215.

Fischbach GD (1970) Synaptic potential recorded in cell cultures of dissociated nerve and muscle cells in low density cultures. Science 169:1331-1333.

Floeter MK, Jones EJ (1984) Connections made by transplants to the cerebral cortex of rat brains damaged in utero. J Neurosci 4:14l-150.

Hendry SHC, Hockfield S, Jones EG, McKay R (1984) Monoclonal antibody that identifies subsets of neurons in the central visual system of monkey and cat. Nature 307:267-269.

Hicks SP, D'Amato CJ (1968) Cell migrations to the isocortex in the rat. Anat Rec 160:619-634.

Hockfield S, McKay RDG (1983) A surface antigen expressed by a subset of neurons in the vertebrate central nervous system. Proc Natl Acad Sci USA 80:5758-5761.

Hohmann CI (1989) Expression of cholinergic markers with transplants of immature mouse neocortex into adult mouse parietal cortex. Anat Embryol 180:535-541.

Horton HL, Levitt P (1988) A unique membrane protein is expressed on early developing limbic system axons and cortical targets. J Neurosci 8:4653-4661.

Huang FL, Yoshida Y, Nakabayashi H, Young WS III, Huang K-P (1988) Immunocytochemical localization of protein kinase $\mathrm{C}$ isozymes in rat brain. J Neurosci 8:4734-4744

Innocenti GM (1981) Growth and reshaping of axons in the establishment of visual callosal connections. Science 212:824-827.

Innocenti GM, Caminiti R (1980) Postnatal shaping of callosal connections from sensory areas. Exp Brain Res 38:381-394.

Ivy GO, Akers RM, Killackcy HP (1979) Differential distribution of callosal projection neurons in the neonatal and adult rat. Brain Res 173:532-537.

Jensen KF, Killackey HP (1984) Subcortical projections from ectopic neocortical neurons. Proc Natl Acad Sci USA 81:964-968.

Kalb RG, Hockfield S (1988) Molecular evidence for early activitydependent development of hamster motor neurons. J Neurosci 8 : 2350-2360.

Kalb RG, Hockfield S (1990) Large diameter primary afferent input is required for expression of CAT-301 proteoglycan on the surface of motor neurons. Neuroscience 34:391-401.

Keller F, Levitt $P$ (1989) Developmental and regeneration-associated regulation of the limbic system associated membrane protein in explant cultures of the rat brain. Neuroscience 28:455-474.

Keller F, Rimvall K, Barbc M, Lcvitt P (1989) A membrane glycoprotein associated with the limbic system mediates the formation of the septo-hippocampal pathway in vitro. Neuron 3:551-561.

Kriegstein AR, Dichter MA (1983) Morphological classification of rat cortical neurons in cell culture. J Neurosci 3:1634-1647.

Landis SC (1980) Developmental changes in the neurotransmitter properties of dissociated sympathetic neurons: a cytochemical study of the effects of medium. Dev Biol 77:349-361.

Landis SC, Jackson PC, Fredier JR, Thibault J (1987) Catecholaminergic properties of cholinergic neurons and synapses in adult rat ciliary ganglion. J Neurosci 7:3574-3587.

Levine JM, Stallcup WB (1987) Plasticity of developing cerebellar cells in vitro studied with antibodies against the NG2 antigen. J Neurosci 7:2721-2731.

Levitt P (1984) A monoclonal antibody to limbic system neurons. Science 223:299-301.

Levitt P (1985) Relating molecular specificity to normal and abnormal brain development. Ann NY Acad Sci 450:239-246.

Levitt P, Pawlak-Byczkowska E, Horton HL, Cooper V (1986) The assembly of functional systems in the brain: molecular and anatomical studies of the limbic system. In: Neurobiology of Down syndrome (Epstein CJ, ed), pp 195-210. New York: Raven.

Lillien LE, Raff MC (1990) Analysis of cell-cell interactions that control type-2 astrocyte development in vitro. Neuron 4:525-534.

Lugo DI, Roberts JL, Pintar JE (1989) Analysis of proopiomelanocortin gene expression during prenatal development of the rat pituitary gland. Mol Endocrinol 3:1313-1324.

Lund RD, Mustardi MJ (1977) Development of genicular-cortical pathway in rat. J Comp Ncurol 173:289-305.

Margolis FL (1972) A brain protein unique to the olfactory bulb. Proc Natl Acad Sci USA 69:1221-1224.

Mattson MP, Guthrie PB, Kater SB (1988a) Intracellar messengers in the generation and degeneration of hippocampal neuroarchitecture. J Neurosci Res 21:447-464. 
Mattson MP, Lee RE, Adams ME, Guthrie PB, Kater SB (1988b) Interactions between entorhinal axons and target hippocampal neurons: a role for glutamate in the development of hippocampal circuitry. Neuron 1:865-876.

McConnell SK (1988) Fates of visual cortical neurons in the ferret after isochronic and heterochronic transplantation. J Neurosci 8:945974.

McConnell SK, Kaznowski CE (1990) Laminar commitment occurs prior to migration in the developing cerebral cortex. Soc Neurosci Abstr 16:1272.

McKay RDG, Hockfield S, Johansen J, Thompson I, Frederiksen K (1983) Surface molecules identify groups of growing axons. Science 222:788-794.

McLoon LK, Lund RD, McLoon SC (1982) Transplantation of reaggregates of embryonic neural retinae to neonatal rat brain: differentiation and formation of connections. J Comp Neurol 205:179-180.

McMorris FA, Dubois-Dalcq M (1988) Insulin-like growth factor I promotes cell proliferation and oligodendroglial commitment in rat glial progenitor cells developing in vitro. J Neurosci 21:199-209.

Miller RH, Ffrench-Constant C, Raff MC (1989) The macroglial cells of the rat optic nerve. Annu Rev Neurosci 12:517-534.

Mochly-Rosen D, Basbaum AI, Koshland DE Jr (1987) Distinct cellular and regional localization of immunoreactive protein kinase $C$ in rat brain. Proc Natl Acad Sci USA 84:4660-4664.

Morris JL, Gibbins IL (1989) Co-localization and plasticity of transmitters in peripheral autonomic and sensory neurons. Int $\mathbf{J}$ Neurosci 7:521-531.

Moskal JR, Trisler D, Schneider MD, Nirenberg M (1986) Purification of a membrane protein distributed in a topographic gradient in chicken retina. Proc Natl Acad Sci USA 83:4703-4733.

Notter MFD, Hansen JT, Okawaras, Gash DM (1989) Rodent and primate adrenal medullary cells in vitro: phenotypic plasticity in response to coculture with C6 glioma cells or NGF. Exp Brain Res 76: $38-46$.

Nowakowski RS (1987) Basic concepts of CNS development. Child Dev 58:568-595.

O'Leary DDM (1989) Do cortical areas emerge from a protocortex? Trends Neurosci 12:400-406.

O'Leary DDM, Stanfield BB (1986) A transient pyramidal tract projection from the visual cortex in the hamster and its removal by selective collateral elimination. Dev Brain Res 27:87-99.

O'Leary DDM, Stanfield BB (1989) Selective elimination of axons extended by developing cortical neurons is dependent on regional locale: experiments utilizing fetal cortical transplants. J Neurosci 9: 2230-2246.

O'Leary DDM, Gerfin GK, Cowan WM (1983) 'The development and restriction of the ipsilateral retinofugal projection in the chick. Dev Brain Res 10:93-109.

Patterson PH, Chun LL (1977) The induction of acetylcholine synthesis in primary cultures of dissociated rat sympathetic neurons. II. Developmental aspects. Dev Biol 60:473-481.

Potter DD, Landis SC, Matsumoto SG, Furshpan EJ (1986) Synaptic functions in rat sympathetic neurons in microcultures. II. Adrenergic/ cholinergic dual status and plasticity. J Neurosci 6:1080-1098.

Raedler E, Raedler A, Felhaus S (1980) Dynamic aspects of neocortical histogenesis in the rat. Anat Embryol 158:253-269.

Raff MC, Abney ER, Fok-Seang J (1985) Reconstitution of a developmental clock in vitro: a critical role for astrocytes in the timing of oligodendrocyte differentiation. Cell 42:61-69.

Rakic P (1974) Neurons in the rhesus monkey cortex: systemic relation between time of origin and eventual disposition. Nature 250:31-34.

Rakic P (1988) Specification of cerebral cortical areas. Science 241: 170-176.

Reh TA (1987) Cell-specific regulation of neuronal production in the larval frog retina. J Neurosci 7:3317-3324.

Rohrer H, Thoenen H (1987) Relationship between differentiation and terminal mitosis: chick sensory and ciliary neurons differentiate after terminal mitosis of precursor cells, whereas sympathetic neurons continue to divide after differentiation. J Neurosci 7:3739-3748.

Rothman TP, Specht LA, Gershon MD, Joh TH, Teitelman G, Pickel VM, Reis DJ (1980) Catecholamine biosynthetic enzymes are expressed in replicating cells of the peripheral but not central nervous system. Proc Natl Acad Sci USA 77:6221-6225.

Ruegg MA, Staeklei ET, Lanz RB, Streit P, Sonderegger P (1989) A homologue of the axonally secreted protein axonin-1 is an integral membrane protein of nerve fiber tracts involved in neurite fasciculation. J Cell Biol 109:2363-2378.

Schlagger BL, O'Leary DDM (1989) Embryonic rat neocortex transplanted homotopically into newborn neocortex develops area appropriate features. Soc Neurosci Abstr 15:1050.

Schwob JE, Gottlieb DI (1988) Purfication and characterization of an antigen that is spatially segregated in the primary olfactory projection. J Neurosci 8:3470-3480.

Simmons PA, I emmon V, Pearlman AI, (1982) Afferent and efferent connections of the striate and extrastriate visual cortex of the normal and reeler mouse. J Comp Neurol 211:295-308.

Smart IHM, Smart I (1977) The location of nuclei of different labelling intensities of autoradiographs of the anterior forebrain of postnatal mice injected with ${ }^{3} \mathrm{H}$ thimidine on the eleventh and twelfth days post conception. J Anat 123:513-525.

Stanfield BB, O'Leary DDM (1985) Fetal occipital cortical-neurons transplanted to the rostral cortex can extend and maintain a pyramidal tract axon. Nature 31 3:135-137.

Steindler DA, Colwell SA (1976) Reeler mutant mouse: maintenance of appropriate and reciprocal connections in the cerebral cortex and thalamus. Brain Res 105:386-393.

Stemple DL, Mahanthappa NK, Anderson DJ (1988) Basic FGF induces neuronal differentiation, cell division and NGF dependence in chromaffin cells: a sequence of events in sympathetic development. Neuron 1:517-525.

Stevens LM, Landis SC (1990) Target influences on transmitter choice by sympathetic neurons developing in the anterior chamber of the eye. Dev Biol 137:109-124.

Sur M, Frost DO, Hockfield S (1988) Expression of a surface-associated antigen on Y-cells in the cat lateral geniculate nucleus is regulated by visual experience. J Neurosci 8:874-882.

Sur M, Pallas SL, Roe AW (1990) Cross-modal plasticity in cortical development: differentiation and specification of sensory neocortex. Trends Neurosci 13:227-233.

Thanos S, Bonhoffer F, Rutishauser U (1984) Fiber-fiber interaction and tectal cues influence the development of the chick retinotectal projection. Proc Natl Acad Sci USA 81:1906-1910.

Thierry JP, Duband J-L, Rutishauser U, Edelman GM (1982) Cell adhesion molecules in early chicken embryogenesis. Proc Natl Acad Sci USA 79:6737-6741.

Thierry JP, Duband J-L, Tucker GC (1985) Cell migration in the vertebrate embryo. Annu Rev Cell Biol 1:91-113.

Valentino KL, Reichardt LF (1985) Application of monoclonal antibodies to neuroscience research. Annu Rev Neurosci 8:199-232.

Verhaagen J, Oestreicher AB, Gispen WH, Margolis FL (1989) The expression of the growth associated protein $\mathrm{B50/GAP} 43$ in the olfactory system of neonatal and adult rats. J Neurosci 9:683-691.

von der Weid PY, Zurn AD (1990) Identification of a 120-kD surface glycoprotein distinguishing cultured superior cervical ganglion from ciliary ganglion neurons. Dev Neurosci 12:106-115.

Waxman S, Dichter M, Hartwieg E, Matheson J (1977) Recapitulation of normal neuro-glial relations in dissociated cell cultures of dorsal root ganglia. Brain Res 122:344-350.

Wise SP, Jones EG (1978) Development studies of thalamocortical and commissural connections in the rat somatic sensory cortex. $\mathbf{J}$ Comp Neurol 228:187-208.

Wolff JR, Rickman M, Chronwall BM (1979) Axo-glial synapses and GABA-accumulating glial cells in the embryonic neocortex of the rat. Cell Tissue Res 201:239-248.

Woolsey TA, Van der Loos H (1970) The structural organization of layer IV in the somatosensory region (SI) of the mouse cerebral cortex: the description of a cortical field composed of discrete cytoarchitectonic units. Brain Res 17:205-242.

Yamamoto M, Buyer AM, Schwarting GA (1985) Fucose containing glycolipids are stage- and region-specific antigens in developing embryonic brain of rodents. Proc Natl Acad Sci USA 82:3045-3049.

Zacco A, Cooper V, Chantler PD, Hyland-Fisher S, Horton HL, Levitt $P$ (1990) Isolation, characterization and ultrastructural analysis of the limbic system-associated membrane protein (LAMP), a protein expressed by neurons comprising functional neural circuits. J Neurosci 10:73-90.

Zaremba S, Guimaraes A, Kalb RG, Hockfield S (1989) Characterization of an activity-dependent, neuronal surface proteoglycan identified with monoclonal antibody Cat-301. Neuron 2:1207-1209. 